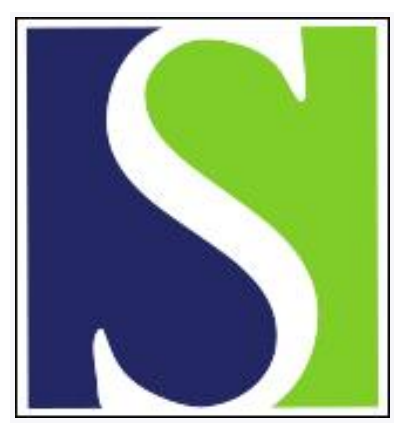

Scand J Work Environ Health 1983;9(4):327-331

https://doi.org/10.5271/sjweh.2404

Issue date: Aug 1983

Biological half-time of cadmium in the blood of workers after cessation of exposure.

by Jarup L, Rogenfelt A, Elinder CG, Nogawa K, Kjellstrom T

This article in PubMed: www.ncbi.nlm.nih.gov/pubmed/6635611

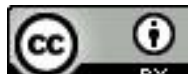




\title{
Biological half-time of cadmium in the blood of workers after cessation of exposure
}

\author{
by Lars Järup, MB, ${ }^{1}$ Artur Rogenfelt, MD, ${ }^{2}$ Carl-Gustaf Elinder, MD, ${ }^{1}$ \\ Koji Nogawa, MD, ${ }^{3}$ Tord Kjellström, $\mathrm{MD}^{4}$
}

\begin{abstract}
JÄRUP L, ROGENFELT A, ELINDER C-G, NOGAWA K, KJELLSTRÖM T. Biological half-time of cadmium in the blood of workers after cessation of exposure. Scand $j$ work environ health 9 (1983) 327-331. The biological half-time of cadmium in the blood of previously exposed workers was estimated after the cessation of exposure. Five men were followed for a period of 10 to 13 years. One-compartment and two-compartment exponential elimination models were used to describe the decrease in blood cadmium levels over time. The best fit to the observed data was obtained with a twocompartment model. The half-times estimated from this model ranged from 75 to $128 \mathrm{~d}$ for the fast component and from 7.4 to 16.0 years for the slow component. The results confirm that there is a very long whole-body biological half-time for cadmium, and the estimated half-times are similar to those obtained with different methods.
\end{abstract}

Key terms: metabolic model.

The decline in the blood cadmium of workers after the cessation of exposure to cadmium has been studied to a limited extent only.

Most estimations of the biological halftime in the blood of human beings shortly after the cessation of exposure are made according to a one-exponential elimination model. In an earlier study (10), 25 solderers were followed for 15 months after the cessation of exposure. The periods of exposure varied from 8 months to 17 years (average values for two groups of workers). For 11 solderers it was possible to analyze the decay kinetics more closely. The decay curves of these workers fitted

1 Department of Environmental Hygiene of the Karolinska Institute and the National Institute of Environmental Medicine, Stockholm, Sweden.

2 Gränges Aluminium, Finspảng, Sweden.

3 Department of Hygiene, Kanazawa Medical University, Uchinada-macni, Ishikawa-ken, Japan.

4 Department of Community Health, Medical School, University of Auckland, New Zealand.

Reprint requests to: Dr L Järup, Department of Environmental Hygiene, Karolinska Institute, PO Box 60400, S-10401 Stockholm, Sweden. single exponential functions. The biological half-times ranged from 25 to $146 \mathrm{~d}$, the median value being $41 \mathrm{~d}$. The authors concluded that a one-compartment exponential elimination model is too simple to describe the blood cadmium curves and that the rapid decline in blood cadmium after the cessation of exposure did not reflect the total body biological halftime.

Based on the accumulation of cadmium in kidney with age, it has been estimated that the total body biological half-time for cadmium is very long, probably 10 to 30 years (2).

Data on the accumulation of cadmium in blood after a sudden increase in exposure can also be used for estimating the half-time of the fast component. Based on data from 17 workers, an average of $77 \mathrm{~d}$ was suggested, and this estimate was used in developing an eight-compartment kinetic model for the metabolism of cadmium (3).

So far, it has not been possible to calculate, with any accuracy, the slow component of the biological half-time of cadmium in the blood of human beings. The present study was carried out to investigate this particular problem. 
Table 1. Age, smoking habits, years of exposure to cadmium, estimated total inhaled amount of cadmium for each subject, and urinary electrophoretic patterns.

\begin{tabular}{|c|c|c|c|c|c|c|c|}
\hline $\begin{array}{l}\text { Worker } \\
\text { number }\end{array}$ & Sex & $\begin{array}{l}\text { Year of } \\
\text { birth }\end{array}$ & $\begin{array}{l}\text { Smoking habits } \\
\text { (cigarettes/d) }\end{array}$ & $\begin{array}{l}\text { Employment } \\
\text { year }\end{array}$ & $\begin{array}{l}\text { Exposure } \\
\text { period }\end{array}$ & $\begin{array}{l}\text { Dosea } \\
\left(\mathrm{mg} \cdot \mathrm{h} / \mathrm{m}^{3}\right)\end{array}$ & $\begin{array}{l}\text { Urinary electropho- } \\
\text { retic patterns }\end{array}$ \\
\hline 1 & Male & 1917 & 7 & 1938 & $1964-1971$ & 785 & $\begin{array}{l}\text { Tubular damage } \\
\text { (diagnosed 1969, } \\
\text { confirmed 1981) }\end{array}$ \\
\hline 2 & Male & 1921 & $\begin{array}{l}35 \\
\text { (After 1962 } \\
\text { nonsmoker) }\end{array}$ & 1959 & $1964-1970$ & 635 & $\begin{array}{l}\text { Tubular damage } \\
\text { (diagnosed 1969, } \\
\text { confirmed 1981) }\end{array}$ \\
\hline 3 & Male & 1930 & $\begin{array}{l}35 \\
\text { (After 1979 } \\
\text { nonsmoker) }\end{array}$ & 1964 & $1964-1971$ & 865 & Normal (1969-1981) \\
\hline 4 & Male & 1920 & 15 & 1964 & $1964-1971$ & 757 & Normal (1969-1981) \\
\hline 5 & Male & 1940 & 15 & 1963 & $1964-1968$ & 399 & Normal (1969-1981) \\
\hline
\end{tabular}

a The dose was estimated by multiplying the workhours in the exposed area by the air cadmium values (in mg/ $\left.\mathrm{m}^{3}\right)$. The air cadmium values were obtained with fixed measuring equipment, and the exposure dose should thus
only be read as an indication of the individual dose.

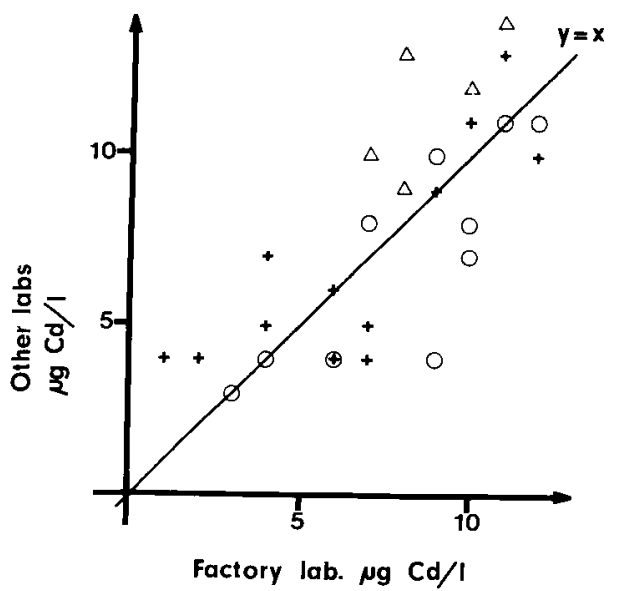

Fig 1. Comparison of blood cadmium values obtained by the factory laboratory and three other independent laboratories. $(1 \mu \mathrm{gCd} / \mathrm{I}=8.9 \mathrm{nmol} \mathrm{Cd} /$ l) $(+=1971, \Delta=1974, \mathrm{O}=1980)$

\section{Subjects and methods}

Five workers in a copper-cadmium alloy factory were studied for a period of 10 to 13 years $(1968-1981)$ after the cessation of exposure. These subjects were selected from a larger group of occupationally exposed workers. The five men in this study were the only ones with sufficiently long follow-up periods to make the accurate calculation of the slow component of the biological half-time for cadmium in the blood possible. Personal data, time of employment, and exposure data are shown in table 1. Two of the workers had developed tubular proteinuria according to the urinary electrophoretic patterns (table 1). Blood samples were collected at irregular intervals (usually once every 3 months) during the whole period and analyzed in the laboratory of the factory. On the average 37 sets of data were obtained for each worker (range $31-43$ ). The analysis of cadmium in blood utilized a spectrographic method from 1968 to 1976, and an atomic absorption method from 1976 on (7). The standard errors for the measuring procedures were $2 \mu \mathrm{g} \mathrm{Cd} / 1(17.8 \mathrm{nmol} / \mathrm{l})$ and $1 \mu \mathrm{g} \mathrm{Cd} / 1(8.9 \mathrm{nmol} / \mathrm{l})$, respectively, at a mean value of $6.4 \mu \mathrm{g} \mathrm{Cd} / \mathrm{l}(56.9 \mathrm{nmol} / \mathrm{l})$ and a range of 1 to $40 \mu \mathrm{g} \mathrm{Cd} / \mathrm{l}$ ( 8.9 to 356 $\mathrm{nmol} / \mathrm{l}$ ).

The blood samples were also sent to other laboratories on three different occasions (1971, 1974, and 1980) for a check of the validity of the data. The results obtained by the other laboratories corresponded fairly well with the results obtained in the factory laboratory, as can be seen in fig 1 (7).

The data on blood cadmium from each worker were then fitted to the following equations:

$$
\begin{aligned}
& \mathrm{B}-\mathrm{Cd}=\mathrm{a}_{1} \cdot \mathrm{e}^{-\mathrm{a}_{2} \cdot \mathrm{t}} \\
& \text { (one-exponential model) }
\end{aligned}
$$

and

$$
\begin{aligned}
& \mathrm{B}-\mathrm{Cd}=\mathrm{a}_{1} \cdot e^{-\mathrm{a}_{2} \cdot t}+\mathrm{a}_{3} \cdot e^{-\mathrm{a}_{4} \cdot t} \\
& \text { (two-exponential model) }
\end{aligned}
$$

using the Nord Computer and STATPAC program, package of the Karolinska Institute, Department of Statistics. The STATPAC program uses a nonlinear curve-fitting routine (5) that employs Marquardt's iterative least-square method 
Table 2. Biological half-time for cadmium in blood after the cessation of exposure. Constants obtained when a two-compartment mathematical model $\left(B-C d=a_{1} \cdot e^{-a_{2} \cdot t}+a_{3} \cdot e^{-a_{4} \cdot t}\right)$ was fitted to data on blood cadmium of five individuals over a period of 10 to 13 years after the cessation of exposure.

\begin{tabular}{|c|c|c|c|c|c|c|c|c|c|c|c|c|c|c|}
\hline \multirow{4}{*}{$\begin{array}{l}\text { Worker } \\
\text { number }\end{array}$} & \multirow{3}{*}{\multicolumn{2}{|c|}{$a_{1}$}} & \multirow{3}{*}{\multicolumn{2}{|c|}{$a_{2}$}} & \multirow{3}{*}{\multicolumn{2}{|c|}{$a_{3}$}} & \multirow{3}{*}{\multicolumn{2}{|c|}{$\mathbf{a}_{4}$}} & \multicolumn{6}{|c|}{ Half-time } \\
\hline & & & & & & & & & \multirow{2}{*}{\multicolumn{2}{|c|}{$\begin{array}{l}\text { Fast component } \\
\text { (d) }\end{array}$}} & \multicolumn{4}{|c|}{ Slow component } \\
\hline & & & & & & & & & & & \multicolumn{2}{|r|}{ Days } & \multicolumn{2}{|c|}{ Years } \\
\hline & Mean & $\mathrm{SD}$ & Mean & SD & Mean & $\mathrm{SD}$ & Mean & SD & Mean & Range & Mean & Range & Mean & Range \\
\hline $\begin{array}{l}1 \\
2 \\
3 \\
4 \\
5\end{array}$ & $\begin{array}{r}4.4 \\
6.6 \\
9.5 \\
6.6 \\
27.6\end{array}$ & $\begin{array}{l}2.0 \\
1.8 \\
2.1 \\
1.8 \\
1.7\end{array}$ & $\begin{array}{c}0.0079 \\
0.0093 \\
0 \\
0.0054 \\
0.0064\end{array}$ & $\begin{array}{c}0.0075 \\
0.0056 \\
0.0034 \\
0.0009\end{array}$ & $\begin{array}{l}27.0 \\
35.8 \\
21.5 \\
19.2 \\
11.2\end{array}$ & $\begin{array}{l}1.1 \\
0.9 \\
0.7 \\
1.1 \\
0.8\end{array}$ & $\begin{array}{l}0.00026 \\
0.00025 \\
0.00018 \\
0.00014 \\
0.00012\end{array}$ & $\begin{array}{l}0.00002 \\
0.00001 \\
0.00002 \\
0.00002 \\
0.00002\end{array}$ & $\begin{array}{c}88 \\
75 \\
\cdots \\
128 \\
108\end{array}$ & $\begin{array}{r}45-1,732 \\
47-\quad 187 \\
\cdots \\
81-\quad 315 \\
95-\quad 126\end{array}$ & $\begin{array}{l}2,666 \\
2,773 \\
3,851 \\
4,951 \\
5,776\end{array}$ & $\begin{array}{l}2,475-2,888 \\
2,666-3,014 \\
3,466-4,332 \\
4,332-5,776 \\
4,951-6,931\end{array}$ & $\begin{array}{r}7.4 \\
7.7 \\
10.7 \\
13.8 \\
16.0\end{array}$ & $\begin{array}{r}6.9-8.0 \\
7.4-8.4 \\
9.6-12.0 \\
12.0-16.0 \\
13.8-19.3\end{array}$ \\
\hline
\end{tabular}

(6). Fitting biological data to a sum of exponential functions using this method may give rise to uncertainty in the results, as pointed out by Lanczos, cited by Fröberg (4).

\section{Results}

The best fit was obtained with the twoexponential model. Both the final chisquare values and the number of outliers were lower than those obtained with the one-exponential model, the result being a better description of the data.

The biological half-time for cadmium in the blood of the five workers ranged from 75 to $128 \mathrm{~d}$ for the fast component (4 workers) and from 7.4 to 16.0 years for the slow component (table 2). The constants $\mathrm{a}_{1}$ and $\mathrm{a}_{3}$ in table 2 correspond to the proportion of blood cadmium that would be related to the fast and slow component at $t=0$, ie, on the last day of exposure. For four of the workers (numbers $1-4)$ the slow component constant $\left(a_{3}\right)$ was higher (range 19.2-35.8) in comparison to the fast component constant $\left(a_{1}\right)$ (range 4.4-9.5). However, worker 5, who had stopped working with cadmium as early as 1968 , displayed an $\mathrm{a}_{3}$ constant of 11.2 , compared to an $a_{1}$ constant of 27.6, ie, the fast component constant was higher than the slow component constant.

Two workers with tubular damage, as evident from their urinary electrophoretic patterns (table 1), had shorter biological half-times (7 years, slow component) than the other three workers (11 to 16 years).
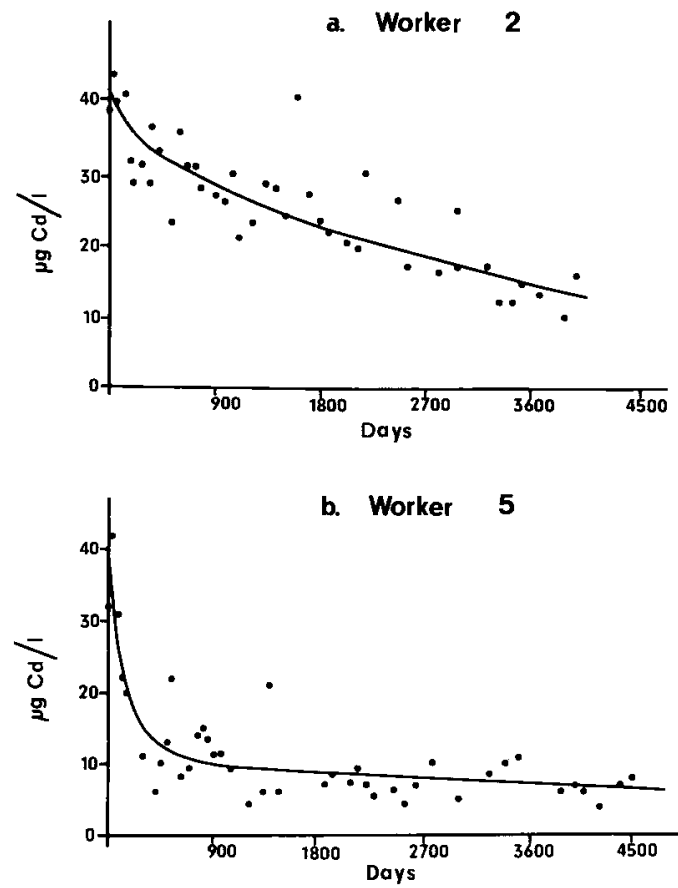

Fig 2. Decrease in blood cadmium in two workers after cessation of exposure. $(1 \mu \mathrm{g} \mathrm{Cd} / 1=8.9 \mathrm{nmol}$ $\mathrm{Cd} / \mathrm{I})$

The elimination curves for two of the workers are shown in fig 2 . They represent one nonsmoking male with tubular damage and one current smoker with no sign of tubular dysfunction.

When the data were fitted to the oneexponential model, the calculated biological half-times for the five workers ranged from 6.9 to 10.6 years.

The blood cadmium values for all of the five workers were also merged into one data file, and a mean elimination curve 
was fitted to the data with both elimination models. The biological half-times were then calculated and found to be 7.7 years for the one-exponential model. Results obtained using the two-exponential model were $91 \mathrm{~d}$ for the fast component and 9.3 years for the slow component.

\section{Discussion}

In this study the exposed workers were followed for an unusually long period of time (10 to 13 years) after the cessation of exposure to cadmium. Four of the workers (numbers 1-4) had a constant $a_{3}$ which was larger than $a_{1}$ (table 2). Thus a major part of the blood cadmium in these workers was related to the slow component. For one of the workers (number 5 , table 1), $a_{1}$ was larger than $a_{3}$. This man was exposed to relatively high concentrations of cadmium between 1964 and 1968 , and it is therefore reasonable to assume that the larger proportion of his blood cadmium should be related to the fast component.

According to the metabolic model (3) the constant $a_{1}$ can be assumed to represent recent exposure, whereas the constant $a_{3}$ should be proportional to the body burden of cadmium.

The range of the fast component in the two-exponential elimination model was 75 to $128 \mathrm{~d}$, which is within the limits of the values obtained in the earlier study (10). The range in that particular study was 25 to $146 \mathrm{~d}$. The estimated slow component of the biological half-time for the three workers without tubular damage ranged from 11 to 16 years, which is in accordance with the model proposed by Kjellström \& Nordberg (3) and earlier estimations of the total body and kidney biological halftime (2).

The levels of blood cadmium that were reached subsequent to between 10 and 13 years of follow-up, after the cessation of exposure, ranged from 8 to $15 \mu \mathrm{gd} / \mathrm{l}$ ( 71.2 to $133.5 \mathrm{nmol} / \mathrm{l})$, which is significantly higher than normal blood cadmium levels. A recent study on Swedish men not subject to occupational exposure showed that the median blood cadmium level for nonsmokers is $0.2 \mu \mathrm{g} \mathrm{Cd} / 1(1.8 \mathrm{nmol} / \mathrm{l})$, and for smokers $1.6 \mu \mathrm{g} \mathrm{Cd} / 1$ (14.2 nmol/l) (1).

Attempts to estimate the biological half-time of cadmium in humans with ra- dioactive isotopes have also been made. Yamagata et al (11), as cited by Takabatake (9), studied the retention of cadmium in the body of an experimental subject who had ingested rice containing ${ }^{115} \mathrm{cad}$ mium. Using the retention curve, they extrapolated the absorption rate to be approximately 7 (range 5-10) \%. They assumed that the total body burden of cadmium for the experimental person was 30 to $40 \mathrm{mg}$ and that the daily ingestion of cadmium was about $0.03 \mathrm{mg}$. Using these figures and a two-exponential elimination model, they calculated the biological half-time of the slow component to be 20 years or more. The period of observation was rather short, however, and the accuracy of the obtained values is therefore limited. Nevertheless their estimate agrees well with the biological half-times of the slow component found in the present study.

Shaikh \& Smith (8) studied 12 volunteers, who ingested beef kidney containing ${ }^{115} \mathrm{cadmium}$ or ${ }^{109} \mathrm{cadmium}$. Whole-body retention was monitored in the subjects for 56 to $808 \mathrm{~d}$. The best fit to the data was obtained with three exponentials. The three components of the curve had biological half-times of 1.58, 33.7, and 9,605 d (26.3 years), respectively.

This study agrees with earlier estimations of the biological half-time of cadmium, even though the other estimations were obtained with methods differing from the one used in the present study. The slow component of the biological halftime of cadmium in blood after the cessation of exposure and the whole-body half-time of cadmium are in the range 10 to 20 years.

\section{Acknowledgment}

We want to thank Mr R Skagerwall, the Karolinska Institute, Department of Statistics, for his helpful assistance in using the mathematical modeling tools required for the nonlinear curve fitting.

\section{References}

1. Elinder C-G, Friberg L, Lind B, Jawaid M. Lead and cadmium levels in blood samples from the general population of Sweden. Environ res (in press). 
2. Friberg L, Piscator M, Nordberg GF, Kjellström $T$. Cadmium in the environment. Second edition. CRC Press, Cleveland, $\mathrm{OH} 1974$.

3. Kjellström $T$, Nordberg G. A kinetic model of cadmium metabolism in the human being. Environ res 16 (1978) 248-269.

4. Lanzcos C. Applied analysis. London 1957. In: Fröberg C-E, ed. Lärobok i numerisk analys. Scandinavian University Books, Stockholm, 1962, pp 247-249.

5. McIntosh JEA, McIntosh RP. Mathematical modelling and computers in endocrinology. Springer, Berlin/New York 1980.

6. Marquardt DW. An algorithm for leastsquares estimation of nonlinear parameters. J soc ind appl math 11 (1963) 431-441.

7. Olofsson $\AA$. Teknisk rapport; bestämning av kadmium i blod, 1971-1981. Gränges Metallverken, Finspång 1981. (Intern rapport).

8. Shaikh ZA, Smith JC. Metabolism of orally ingested cadmium in humans. In: Holmstedt B,Lauwerys R, Mercier M, Roberfroid $\mathrm{M}$, ed. Mechanisms of toxicity and hazard evaluation. Elsevier/North Holland Biomedical Press, Amsterdam/New York 1980, pp 569-574.

9. Takabatake E. Experimental studies on humans. In: Tsuchiya K, ed. Cadmium studies in Japan - A review. Elsevier/ North Holland Biomedical Press, Amster$\mathrm{dam} /$ New York 1978, pp 129-132.

10. Welinder $\mathrm{H}$, Skerfving $\mathrm{S}$, Henriksen $\mathrm{O}$. Cadmium metabolism in man. $\mathrm{Br} \mathrm{j}$ ind med 34 (1977) 221-228.

11. Yamagata N, Iwashima K, Nagai T. Gastrointestinal absorption of ingested ${ }^{115} \mathrm{Cd}$ by a man. Bull inst publ health (Tokyo) 24 (1975) $1-6$.

Received for publication: 21 April 1983 